\title{
Review
}

\section{Hegel's political philosophy: On the normative significance of method and system}

Thom Brooks and Sebastian Stein (eds.)

Oxford University Press, 2017, 282pp., ISBN: 978-0198778165

Contemporary Political Theory (2020) 19, S55-S58. https://doi.org/10.1057/s41296018-0267-7; published online 19 September 2018

Thom Brooks and Sebastian Stein's edited volume, Hegel's Political Philosophy, is motivated by an apparent debate between those who base their interpretation of Hegel's political thought on his broader system and method and those who do not. In the introduction, Brooks and Stein write: 'the topic of this book is a new issue that emerges from this debate between the non-metaphysical readings that isolate the Philosophy of Right from its systematic context and metaphysical readings that take the Science of Logic and the wider system into account when they interpret the Philosophy of Right. This difference entails a profound interpretative change concerning the philosophical foundations of Hegel's political thought' (p. 2, emphasis in original).

The thirteen essays in the volume, written by many of the most influential contemporary interpreters of Hegel, suggest that there is no such debate, at least not on these terms. All of these essays work from the assumption that a proper understanding of Hegel's Philosophy of Right depends on recognition of its relationship to his broader philosophical system. Even Allen Wood, whom the editors cite in the introduction as one of the interpreters committed to the antisystematic approach, rejects such an approach in his contribution to the volume. In his rather exasperated response, Wood distinguishes between understanding Hegel's political thought and making normative use of it. Whereas the former requires attention to Hegel's broader system, the latter, he argues, need not rest on any endorsement of that system.

While the book's contributors emphasize different aspects of the relationship between Hegel's logical system and his political thought, they largely agree on the necessity of that relationship for an understanding of Hegel's practical philosophy. Several essays explicate a central logical concept in order to develop a reading of Hegel's practical philosophy. Robert Pippin considers the relationship between

(c) 2018 Springer Nature Limited. 1470-8914 Contemporary Political Theory Vol. 19, S1, S55-S58 
civil society and the state in light of Hegel's concept of actuality. Katerina Deligiorgi argues that the concept of the individual on which Hegel's political thought depends is best understood as a logical form, subject to further specification under particular social conditions. Angelica Nuzzo interprets Hegel's political philosophy in light of his 'logic of action,' arguing that the relationship between the political philosophy and the logic is one of 'correspondence, on different systematic levels, of the structures of action' (p. 123).

To the extent that there is a debate in these pages, it is not about whether or not Hegel's system and method - and thus his metaphysics - may be left out of the interpretive picture, but rather about what Hegel's metaphysical and ontological claims turn out to be. Terry Pinkard's contribution provides an overview of his reading of Hegel as post-Kantian thinker who rejects pre-critical metaphysics. This overview will be familiar to Hegel scholars, but serves as a reminder that metaphysically minimalist interpretations do not leave system and method behind. Furthermore, it nicely sets up Pinkard's conclusions about the social practical conception of subjectivity that undergirds Hegel's practical philosophy.

Hegel's conception of subjectivity is also taken up in Liz Disley's essay, which considers the contrast and potential contradiction between Hegel's view of a socially constituted subjectivity and his view of ethical community as resting on the concept of the autonomous individual. Engaging the work of Judith Butler, Disley argues that the apparent contradiction may be resolved by attending to Hegel's ideas about mutual recognition and mediated autonomy. One result of Disley's view is a more open or incomplete 'system' than Hegel is sometimes believed to have.

A number of essays consider Hegel's understanding of knowledge and truth. Sebastian Stein offers a reading of the relationship between empirical cognition and philosophical knowledge. He argues that, for Hegel, there is such a thing as philosophical knowledge (PK). Our claims - and Hegel's - aim at such knowledge. As the historically situated knowers that we are, however, our claims take the form of potentially conditioned philosophical knowledge, which may turn out to be true or false. Hegel, Stein argues, believes in the unconditionality of PK as the selfthinking of absolute spirit, but remains committed to the view that claimants can always be wrong.

Paul Redding also takes on Hegel's views on knowledge and truth through an engagement with Richard Rorty's Hegel. Redding's Hegel follows Rorty's Hegel in rejecting the search for a God's eye view of truth but departs from him in retaining the possibility of something worth calling 'truth.' Hegel's metaphysics, Redding argues, is not Kant's metaphysical skepticism, but a 'metaphysics of the actual,' a commitment to the possibility of knowledge about the actual world in which we live (p. 43). Redding's account of Hegel's view of truth is therefore more deflationary than Stein's metaphysically robust account. Kevin Thompson's essay, meanwhile, gives a clear and compelling account of the relationship between 
Hegel's philosophical concerns about, on the one hand, knowledge, skepticism, and representationalism and, on the other, his social and political concerns about what account of the sovereign state could avoid such skepticism.

Thom Brooks's essay on crime and punishment is distinctive in the volume for its more narrow focus on a concrete topic within Hegel's practical philosophy. Brooks argues that the consensus view of Hegel's theory of punishment as straightforwardly retributivist is mistaken. The consensus view, Brooks argues, takes Hegel's comments in the Abstract Right section of the Philosophy of Right as Hegel's final word on the matter. Looking into Hegel's discussion in Ethical Life, Brooks argues that Hegel's view is rather more complicated. Hegel thinks that punishment must be 'retributivist' in the sense that it maintains a necessary connection to the crime committed. But the practices and distribution of punishment are likely to shift with circumstances, taking considerations other than strict retribution into account. This view of Hegel's theory of punishment, Brooks argues, takes seriously the structure of the Philosophy of Right, in which Ethical Life is not merely a concretization of ideas already fully articulated in Abstract Right, but rather a development and sublation of them.

Still other essays consider the form of ethical life that Hegel proposes in the Philosophy of Right, asking how and whether it follows from his system and method, and how and whether it might remain compelling today. Richard Dein Winfield shows how the structure of Hegel's political philosophy follows from his logic, and how family, civil society, and the state are necessary aspects of ethical community - even if Hegel errs in his claims about the particular shape that these aspects must take. Klaus Viewig argues that Hegel's endorsement of a particular conception of the monarch as the 'final decider' is at odds with the otherwise logical organization of his political thought. It is, he writes, a 'the only obvious logical faux pas of the Outlines' (p. 135). He suggests that Hegel's apparent mistake was intentional: 'Hegel has - so is my rather audacious interpretation fooled the Prussian censors with considerable finesse and chutzpa and placed his faith in his subsequent interpreters to realize a reconstruction and correction in accordance with the requirements of Hegel's Logic especially' (p. 135, emphasis in original). Viewig argues that complete logical systematicity would require not the positing of the monarch as the universal and final decider, but the citizen, "enabled to participate equally in the creation of the universal' (p. 137). Even if readers disagree with Viewig about Hegel's democratic sympathies, they can see how Hegel fails to track the insights of his own logic to their appropriate conclusion in the political realm.

The most illuminating and provocative contribution to the volume may be Kenneth R. Westphal's 'Hegel's Natural Law Constructivism: Progress in Principle and Practice.' The final essay in the volume defends Hegel's oft-maligned endorsement of a corporate system of representation as an alternative to open democratic elections. Westphal argues that the corporate system is based in Hegel's

(c) 2018 Springer Nature Limited. 1470-8914 Contemporary Political Theory Vol. 19, S1, S55-S58 S57 
natural law constructivism (a view that is only briefly treated here, but developed in more detail in other recent work by Westphal) and aligned with his republicanism. Westphal also touches on some of Hegel's most troubling claims, including his views on gender and the structure of the family, and shows how they might be corrected within the terms of Hegel's own system.

While Westphal's contribution is welcome, one might have hoped that a book considering the relationship between Hegel's logical system and his political thought would have treated his views on gender and the family at greater length. The same is true of Hegel's views on race and colonialism. These are not ancillary concerns. Hegel believed that the patriarchal family and colonial state followed from his system and were necessary on its terms. If he is right, then it is past time to leave Hegel's system behind. If he is wrong, then we need a deeper and more explicit reckoning with the limits and possibilities of reading Hegel's system against his practical commitments. While some of the essays included in Hegel's Political Philosophy suggest ways that such a reckoning might proceed, it would have been good to see more attention devoted to expanding and evaluating those suggestions.

Hegel's Political Philosophy contains a number of insightful essays on the relationship between Hegel's logical system and his practical philosophy. The essays included in the volume suggest that there is no great debate about the fact of that relationship even as they have different ways of approaching it. With no internal structure and a somewhat mistaken premise, however, the book falls short of clarifying what is at stake when we choose one path over another.

Molly Farneth

Haverford College, Haverford, PA 19041, USA mfarneth@haverford.edu 